\title{
Comparative analysis of the Gran Dolina-TD6 (Spain) and Tighennif (Algeria) hominin mandibles
}

Analyse comparée des mandibules d'hominidés de Tighennif(Algérie) et de Gran-Dolina-TD6 (Espagne)

José-Maria Bermúdez de Castro, María Martinón-Torres, Aida GómezRobles, Leyre Prado et Susana Sarmiento

\section{(2) OpenEdition}

\section{Journals}

Édition électronique

URL : https://journals.openedition.org/bmsap/4623

DOI : 10.4000/bmsap.4623

ISSN : $1777-5469$

Éditeur

Société d'Anthropologie de Paris

Édition imprimée

Date de publication : 1 décembre 2007

Pagination : 149-167

ISSN : 0037-8984

Référence électronique

José-Maria Bermúdez de Castro, María Martinón-Torres, Aida Gómez-Robles, Leyre Prado et Susana Sarmiento, "Comparative analysis of the Gran Dolina-TD6 (Spain) and Tighennif (Algeria) hominin mandibles », Bulletins et mémoires de la Société d'Anthropologie de Paris [En ligne], 19 (3-4) | 2007, mis en ligne le 04 janvier 2011, consulté le 01 juin 2021. URL : http://journals.openedition.org/bmsap/4623 ; DOI : https://doi.org/10.4000/bmsap.4623

\section{(c) (i) (9)}

Les contenus des Bulletins et mémoires de la Société d'Anthropologie de Paris sont mis à disposition selon les termes de la licence Creative Commons Attribution-NonCommercial-NoDerivatives 4.0 International License. 


\title{
COMPARATIVE ANALYSIS OF THE GRAN DOLINA-TD6 (SPAIN) AND TIGHENNIF (ALGERIA) HOMININ MANDIBLES

\author{
ANALYSE COMPARÉE DES MANDIBULES D'HOMINIDÉS DE TIGHENNIF \\ (ALGÉRIE) ET DE GRAN-DOLINA-TD6 (ESPAGNE)
}

\author{
José María Bermúdez de Castro ${ }^{1}$, María Martinón-Torres ${ }^{1}$, Aida Gómez-Robles ${ }^{1}$, \\ Leyre Prado ${ }^{1}$, Susana SARmiento ${ }^{1}$
}

AbStract

We present a comparative study of the Tighennif (Algeria) and Gran Dolina-TD6 (Spain) hominin mandibles, which represent two geographically near and contemporaneous populations separated by the Mediterranean sea, in order to test the hypothesis that these populations belong to the same evolutionary lineage, as it has been suggested by some authors. The Tighennif mandibles show a clear primitive structural pattern, derived in some features with regard to the oldest Homo specimens from H. habilis, as well as from the Javanese H. erectus. In addition, the Tighennif specimens share all these derived features with $H$. ergaster and, some of them, with $H$. antecessor. However, the Gran Dolina-TD6 specimens are remarkably smaller than those of Tighennif, and lack the robustness which characterizes the African Pleistocene mandibles. The main difference between both groups in terms of mandibular dimensions can be related to the higher corpus height characteristic of Tighennif specimens. The dental evidence reveals that North African Middle Pleistocene populations are morphologically closer to African Early Pleistocene populations than to TD6 fossils. We conclude that the Spanish and Algerian hominins belong to different hominin lineages. The Tighennif hominins, together with other contemporaneous (Thomas Quarry and Oulad Hamida 1), and perhaps later North African specimens (Sidi Abderrahaman, Salé, and Rabat [Kebitat]) should be considered as a subspecies of the H. ergaster species, i.e. H. ergaster mauritanicus, and may be the result of an evolution in isolation in this African area. In agreement with the mandibular and dental evidences, the Gran Dolina-TD6 hominins could belong to an exclusive Eurasian lineage.

Keywords: Early Pleistocene, North Africa, Europe, hominins, mandibles.

RÉSUMÉ

Nous présentons une analyse comparée des mandibules des hominidés de Tighennif (Algérie) et de la Gran DolinaTD6 (Espagne), qui représentent deux populations proches dans l'espace et le temps mais séparées par la mer Méditerranée, afin de vérifier l'hypothèse que les deux échantillons appartiennent au même lignage évolutif, comme certains auteurs l'ont

1. Centro Nacional de Investigación sobre Evolución Humana, Avenida de la Paz 28, 09005 Burgos, Espagne, e-mail: jm.ber@cenieh.es 
suggéré. Les mandibules de Tighennif ont un pattern morphologique structurel primitif, avec certains caractères dérivés par rapport à ceux des spécimens de $\mathrm{H}$. habilis et de $\mathrm{H}$. erectus de Java. Les mandibules de Tighennif partagent tous ces caractères dérivés avec $\mathrm{H}$. ergaster et quelques uns avec $\mathrm{H}$. antecessor. Néanmoins, les spécimens de la Gran DolinaTD6 sont remarquablement plus petits que ceux de Tighennif, et sont moins robustes que les mandibules du Pléistocène d'Afrique. La principale différence entre les deux échantillons, en ce qui concerne les dimensions mandibulaires, est la grande hauteur du corps de la mandibule des spécimens de Tighennif. Les caractères dentaires révèlent que les populations du Pléistocène moyen du Nord de l'Afrique sont, du point de vue morphologique, plus proches des hominidés du Pléistocène inférieur de l'Afrique que de ceux de la Gran Dolina-TD6. Nous concluons donc que les hominidés de Tighennif et de la Gran Dolina-TD6 appartiennent à deux lignées différentes. Les hominidés de Tighennif pourraient être réunis avec les spécimens contemporains de Thomas Quarry et de Oulad Hamida 1, et peut-être avec d'autres plus tardifs comme ceux de Sidi Abderrahaman, Salé, et Rabat [Kebitat] du Nord de l'Afrique dans une même sous-espèce de H. ergaster, i.e. $\mathrm{H}$. ergaster mauritanicus, qui serait le résultat d'une évolution locale en isolement relatif dans cette région de l'Afrique. Les hominidés de la Gran Dolina-TD6 appartiennent à une lignée exclusive de l'Eurasie, conformément aux données dentaires et mandibulaires.

Mots-clés : Pléistocene inférieur, Nord de l'Afrique, Europe, hominidés, mandibules.

\section{Version abrégée}

Dans ce travail, nous présentons une comparaison métrique et morphologique entre deux échantillons de mandibules fossiles: Tighennif (Algérie) et Gran Dolina-TD6 (Espagne), qui sont proches dans l'espace et le temps, mais séparées par la mer Méditerranée. Le gisement de Tighennif est bien connu par la découverte de trois mandibules complètes, ainsi que par un os pariétal et quelques dents isolées. Tous ces fossiles humains, associés à plusieurs centaines de fossiles de mammifères et à des outillages lithiques inclus dans 1'Oldowayen et l'Acheuléen (Arambourg 1954a, b), représentent les hominidés les plus anciens du Nord de l'Afrique, avec une chronologie de ca. 700000 ans (Geraads et al. 1986).

Le niveau TD6 du gisement de la grotte de la Gran Dolina, située dans la Sierra d'Atapuerca, a livré plus d'une centaine de fossiles humains associés avec des mammifères fossiles et des outils lithiques de tradition oldowayenne (Carbonell et al. 1995). Cet ensemble, localisé sous l'inversion Matuyama/Bruhnes, est daté de ca. 800000 ans B.P. (Parés, Pérez-González 1995, 1999 ; Falguères et al. 1999). L'échantillon de fossiles humains inclut trois fragments de mandibule bien conservés.

Originellement, les hominidés de Tighennif furent inclus dans l'espèce Atlanthropus mauritanicus par Arambourg (1954a) et postérieurement attribués à l'espèce Homo erectus par Le Gros Clark (1964). Les hominidés de la Gran Dolina-TD6 ont été inclus dans l'espèce H. antecessor (Bermúdez de Castro et al. 1997). Certains auteurs ont considéré la possibilité de rassembler les deux échantillons dans la même espèce : H. mauritanicus (Hublin 2001; Stringer 2003). Cependant, ces auteurs n'ont pas présenté une étude formelle pour défendre leur alternative. Par conséquent, l'objectif de ce travail est de tester l'hypothèse que les hominidés de Tighennif et de la Gran Dolina-TD6 représentent une même lignée évolutive sur les deux bords de la mer Méditerranée.

Nos résultats indiquent que les mandibules de Tighennif ont un pattern morphologique structurel primitif, dont certains caractères sont dérivés par rapport à ceux de H.habilis et des spécimens de H. erectus de Java. Les mandibules de Tighennif partagent tous ces caractères avec H. ergaster et quelques-uns avec $H$. antecessor. Néanmoins, les spécimens de la Gran Dolina-TD6 sont remarquablement plus petits que ceux de Tighennif, et sont moins robustes que les mandibules du Pléistocène d'Afrique. La principale différence entre les deux échantillons, en ce qui concerne les dimensions mandibulaires, est la grande hauteur du corps de la mandibule des spécimens de Tighennif. Les caractères dentaires révèlent que les populations du Pléistocène moyen du Nord de l'Afrique sont, du point de vue morphologique, plus proches des hominidés du Pléistocène inférieur de l'Afrique que de ceux de la Gran Dolina-TD6 (Martinón-Torres et al. 2007). 
À partir de ce travail, nous concluons donc que les hominidés de Tighennif et de la Gran Dolina-TD6 appartiennent à deux lignées différentes. Les hominidés de Tighennif pourraient être réunis avec les spécimens contemporains de Thomas Quarry et de Oulad Hamida 1 et peut-être avec d'autres plus tardifs comme ceux de Sidi Abderrahaman, Salé, et Rabat [Kebitat] du Nord de l'Afrique dans une même sous-espèce de H. ergaster, i.e. H. ergaster mauritanicus, qui serait le résultat d'une évolution locale en isolement relatif dans cette région de l'Afrique. Les hominidés de la Gran Dolina-TD6 appartiennent à un groupe exclusif de l'Eurasie, d'après la morphologie mandibulaire et dentaire.

\section{INTRODUCTION}

The sand pit of Tighennif (formerly Ternifine) is located in the village of Palikao, $22 \mathrm{~km}$ east from Mascara in Algeria. Excavations during the 1950s in the Middle Pleistocene sandy sediments of an ancient small lake basin yielded thousands of mammal fossils, as well as Oldowan and Acheulean stone tools (Arambourg 1954a, b). The Tighennif site is particularly known by the finding of three well preserved mandibles, some isolated teeth and one parietal bone, which represent the oldest fossil hominins recovered so far from northwest Africa. The lithic assemblage can be included in the Acheulean technological complex and consists of choppers, chopping tools, polyhedrical spheroids, trihedrons, cores, retouched pieces, large and small flakes, hand axes and cleavers. The artefacts are made of quartzite, sandstone, limestone, and flint (Sahnouni, Derradji in press)

According to the paleontological and paleomagnetic data, the age of Tighennif has been estimated to be ca. 700 kyrs at the early Middle Pleistocene (Geraads et al. 1986). Paleomagnetic studies made on the lower deposits indicated normal polarity, and thus they may be correlated with the Brunnhes Chron. However, Sahnouni and Derradji (in press) do not rule out the correlation with the Jaramillo Subchron. These authors have pointed out the similarities between the Tighennif and Thomas Quarry 1 (level L) sites concerning the macro-mammals and lithic assemblage. The age of the last site has been recently estimated to be ca. $989 \mathrm{kyrs}$ (Rhodes et al. 2006).

The Tighennif human fossil remains were originally classified as Atlanthropus mauritanicus by Arambourg (1954b) together with other remains such as those from Rabat (Thomas, Vallois 1977). These hominins were also later included into Homo erectus (Le Gros Clark 1964), a denomination that is nowadays preferred by some authors to include other North African human fossils such as those from Thomas Quarry and Sidi Abderrahaman (Rightmire 1990). Alternatively, other researchers have preferred to use the denomination $H$. mauritanicus (Hublin 2001; Stringer 2003). Furthermore, Hublin (2001) and Stringer (2003) have considered that the human fossils recovered from Aurora Stratum of the level TD6 in the Gran Dolina site of the Sierra de Atapuerca (Carbonell et al. 1995) could be also included in H. mauritanicus (considering the priority of the name assigned by Arambourg). However, these authors have not presented a formal study to test their hypothesis.

The cave of Gran Dolina (TD) in the Railway Trench of the Sierra de Atapuerca (northern Spain) contains an 18 meters high section formed by a succession of eleven levels, probably deposited from the late Early Pleistocene to the end of the Middle Pleistocene (Parés and PerezGonzález 1999). The lowermost stratigraphic levels, TD1 and TD2, contain sediments of interior facies typical of a closed cave. The paleontological record (pollen and faunal remains) is continuous from TD3 to TD11 (except TD9), and some levels (TD4, 5, 6, 7, 10, and 11) contain abundant stone tools. During the 1994-96 field seasons, near one hundred human fossils were found together with more than one thousand macrovertebrate fossil remains, as well as 268 lithic artefacts included in the Mode 1 Technology (= Oldowan tradition) (Carbonell et al. 1995). The human remains were later included in a new Homo species, $H$. antecessor, considered as possible last common ancestor to Neanderthals and modern humans lineages (Bermúdez de Castro et al. 1997). These fossils have been firmly dated to the late Early Pleistocene (Parés, Pérez González 1995, 1999; Falguères et al. 1999). During the 2003 to 2006 field seasons new findings have significantly enlarged the hominin fossil hypodigm of $H$. antecessor (Carbonell et al. 2005). The TD6 human assemblage now includes three mandibular remains and a large dental sample.

Although the information is obviously limited, we have the possibility of comparing dental and mandibular evidence from two near and almost contemporaneous Pleistocene populations separated by the Gibraltar Strait. The aim of this report is therefore to make a comparative study of the mandibles and teeth recovered from the two sites in order to make possible inferences about the phylogenetic story of the hominins represented in the Tighennif and Gran Dolina-TD human fossil samples. 


\section{THE TD6 AND TIGHENNIF SPECIMENS}

Figures 1 and 2 show the three Tighennif mandibles. In Tighennif 1 both the left and right ramus are damaged and some features of this region are not available. Both the right and left P3-P4 and M1-M3 series are in situ, as well as the root and a part of the crown of the lateral incisors. Tighennif 2 consists of the left half of a well preserved mandible (including the symphysis) that preserves the P3-P4 and M1-M3 series in situ. The most complete mandible is Tighennif 3, which preserves the right I2, C, P3, P4, M1, M2, and M3, and the left P4, M1, M2, and M3 in situ. The three specimens belong to adult individuals.

The TD6 human assemblage includes three mandibular specimens: ATD6-5 is a fragment of the right side of the mandibular body of a juvenile specimen, with M1, M2, and M3 in situ, the latter still enclosed in its alveolus (figure in Rosas, Bermúdez de Castro 1999).

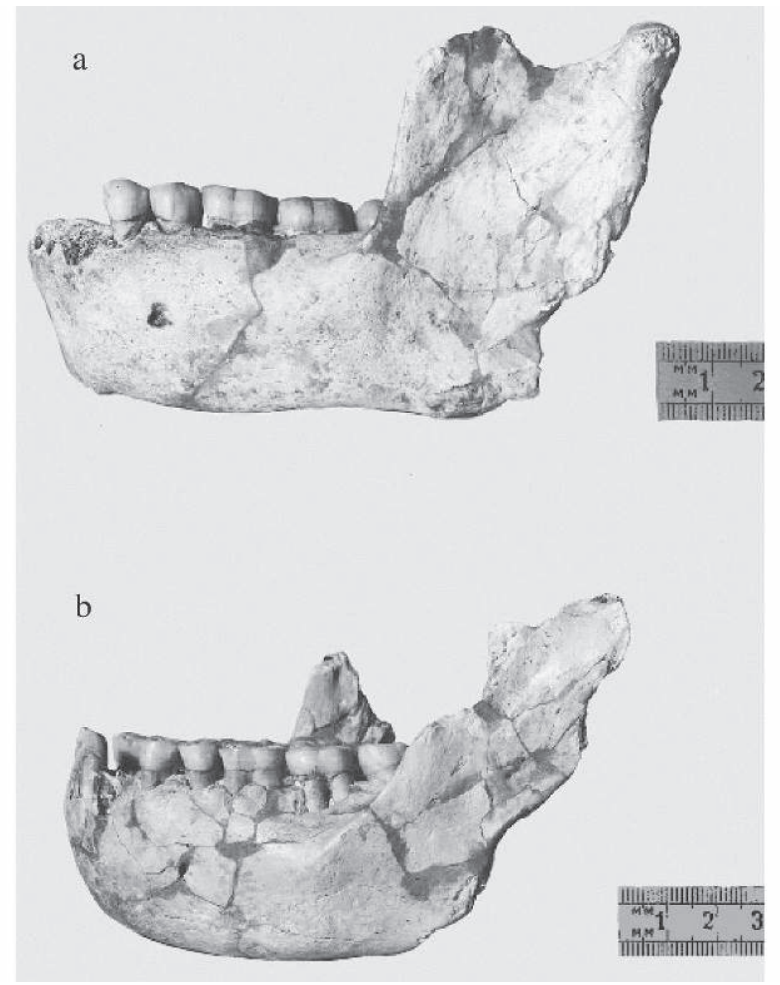

Fig. 1a-Tighennif 1; b-Tighennif 2. The photographs on the originals of Tighennif mandibles were obtained by Marcel Bovis in 1954 and donated to Emiliano Aguirre by Camille Arambourg.

Fig. 1a-Tighennif 1 ; $b$ - Tighennif 2. Les photographies des originaux des mandibules de Tighennif ont été obtenues par Marcel Bovis en 1954 et offertes à Emiliano Aguirre par Camille Arambourg.

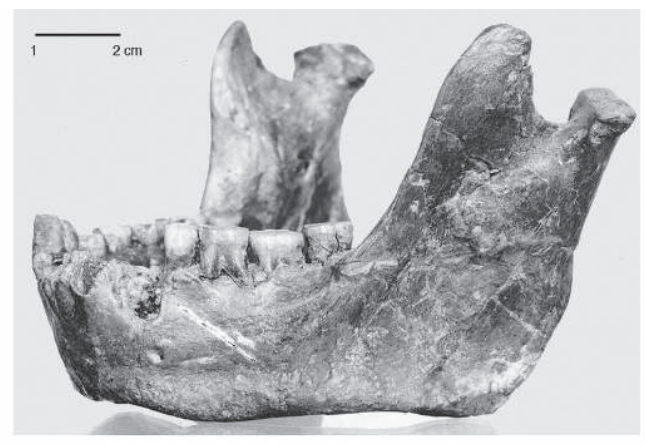

Fig. 2-Left lateral view of Tighennif 3.

Fig. 2 - Vue latérale gauche de Tighennif 3.

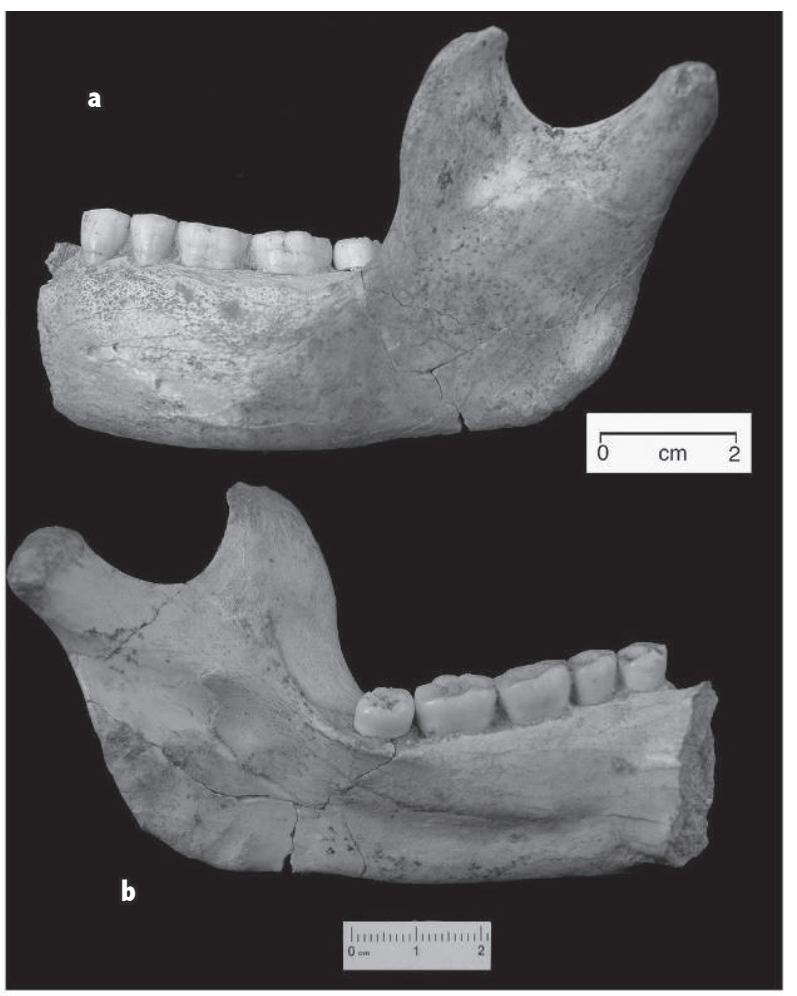

Fig. 3a-Lateral view of ATD6-96; $b-$ medial view of ATD6-96.

Fig. 3a - Vue latérale de ATD6-96; $b$ - vue médiale de ATD6-96.

This specimen, as well as some isolated maxillary and mandibular teeth, belongs to Hominid 1 (the holotype of $H$. antecessor). ATD6-96 (Hominid 7) is the left half of a small and gracile mandible of an adult individual with the premolars and molars in place (fig. 3) (Carbonell et al. 2005). The third specimen, ATD6-113 (Hominid 10) is a 
fragment of the left side of the mandibular body with a part of the ramus, which preserves the M2 and M3 in situ and it was found in the 2006 excavation season. The third molar is fully erupted and exhibits slight occlusal wear at the level of the protoconid and metaconid that only affects the enamel. Thus, this mandible may correspond to a young adult. The increased TD6 human hypodigm allow us now to do a proper comparison with the Tighennif specimens.

\section{METHODS}

For comparative purposes, a large number of fossil Homo mandibles and teeth were included in our study (tables I, II, III). Observations and data were recorded on the following original fossil samples: Atapuerca-Sima de los Huesos, Arago, Atapuerca-TD6, Tighennif, Sangiran, and Dmanisi, as well as on some high-quality casts. We have grouped the specimens into different species in accordance with the criteria of different authors (e.g. Wood 1992; Schwartz, Tattersall 1999 ; Tattersall 2000). Thus, we have differentiated taxonomically the Early Pleistocene East African hominins (H. ergaster) from the Asian Pleistocene hominins (H. erectus). Furthermore, we have distinguished between the Chinese and Javanese H. erectus because, according to different authors, they show some regional and temporal variations (Rightmire 1990; Grimaud-Hervé et al. 2000; Antón 2002; Babá et al. 2003). The species $H$. heidelbergensis includes the European Middle Pleistocene hominins, according to the criteria expressed by Arsuaga et al. (1999) (but see also an alternative opinion in Rightmire 1996). The Dmanisi mandibles were not included in a particular species because their taxonomic status are a current disputed matter among the specialists (e.g. Gabunia,Vekua 1995; Rosas, Bermúdez de Castro 1998; Gabunia et al. 2002; Rightmire et al. 2005).

Features and data of several mandibular specimens were confirmed or obtained from tables 5, 6, and 7 of Rosas (2001) and table 2 of Rosas and Bermúdez de Castro (1999). Our methodological approach is cladistic and the description, definition and evaluation of the status (primitive or derived) of the mandibular features (table IV) are taken from Rosas (2001). Thickness of the mandibular body was measured at the M1 and at lateral prominence location (tables II, III). In both cases, the measurement was taken between the external side of the mandibular body and the most prominent point of the internal side. Height of the mandibular body was taken between the basal and the alveolar borders, keeping the callipers parallel to the external side of the mandibular body. A scatter biplot is provided in order to illustrate the variability of the mandibular corpus robustness (the corpus width at M1 level divided by the corpus height at the same level) against the corpus height. In the D211 Dmanisi mandible we had to do an estimation of the corpus height since the corpus base is broken at the M1 level. The slope of the regression line, the correlation coefficient and the p-value of the regression was calculated for those groups with a sample size large enough to obtain the parameters: H. ergaster, H. erectus, H. heidelbergensis and $H$. neanderthalensis.

The mesiodistal (MD) and buccolingual (BL) dimensions were obtained in the TD6 and Tighennif teeth, according to the technique quoted in Bermúdez de Castro (1993).

\section{COMPARATIVE ANALYSIS}

\section{The mandibles}

As it has been previously pointed out, the Tighennif mandibles are extremely massive and robust (Howell 1960; Arambourg, Hoffstetter 1963), whereas the TD6 specimens are particularly gracile. Nevertheless, before comparing the dimensions of the TD6 mandibles with those of Tighennif it is necessary to consider the possible effect of sexual dimorphism in the specimens size. Judging by the remarkable size difference between the teeth of Hominid 1 (ATD6-5) and Hominid 10 (ATD6-113) from TD6 on one hand, and Hominid 7 (ATD6-96) on the other hand (table I), we can assume that the Hominid 1 and 10 are probably males, whereas Hominid 7 would be female. The dimensions of the upper canine of Hominid 1 are at the upper limit of the variation range of the genus Homo, which supports the sex status of this immature individual. Thus, we think that males and females are present at least in the TD6 sample. Interestingly, the thickness and height of the ATD6-113 mandible (the largest of the Gran Dolina-TD6 sample) are similar to those of Tighennif 2 (the smallest of the North African sample) (table II).

The thickness and height of the mandibular body of the Tighennif mandibles are similar to those of $H$. erectus from Java, whereas the same variables of the TD6 specimens are similar to those of the $H$. erectus from China (table III). The ramus breadth of the ATD6-96 mandible $(40.6 \mathrm{~mm})$ is lower than those of Tighennif $2(45.8 \mathrm{~mm})$ 
and Tighennif $3(47.3 \mathrm{~mm})$. The height of the ramus in ATD6-96 is $60 \mathrm{~mm}$, whereas in Tighennif 2 and 3 this measurement is 78.5 and 85.6 , respectively. According to
Howell (1960), the total length and bicondylar dimensions of Tighennif 3 exceed those of the Mauer mandible.

\begin{tabular}{|c|c|c|c|c|c|c|c|c|c|c|c|c|c|}
\hline \multirow[b]{3}{*}{ Side } & \multirow[b]{3}{*}{ Tooth } & & & & & & & \multicolumn{6}{|c|}{ Gran Dolina-TD6 } \\
\hline & & \multicolumn{2}{|c|}{ Tighennif 1} & \multicolumn{2}{|c|}{ Tighennif 2} & \multicolumn{2}{|c|}{ Tighennif 3} & \multicolumn{2}{|c|}{ H 1} & \multicolumn{2}{|c|}{$\mathrm{H} 7$} & \multicolumn{2}{|c|}{ H 10} \\
\hline & & MD & BL & MD & $\mathrm{BL}$ & MD & $\mathrm{BL}$ & MD & $\mathrm{BL}$ & MD & $\mathrm{BL}$ & MD & $\mathrm{BL}$ \\
\hline $\mathrm{R}$ & 12 & & & & & $(5.6)$ & 7.3 & & & & & & \\
\hline $\mathrm{L}$ & 12 & & & & & & & 7.0 & 7.8 & & & & \\
\hline $\mathrm{R}$ & $\mathrm{C}$ & & & & & 7.8 & 10.3 & & & & & & \\
\hline $\mathrm{L}$ & $\mathrm{C}$ & & & & & & & 8.1 & 10.0 & & & & \\
\hline $\mathrm{R}$ & P3 & 8.5 & 10.2 & & & 8.8 & 10.2 & 8.8 & 10.6 & & & & \\
\hline $\mathrm{L}$ & $\mathrm{P} 3$ & 8.4 & 10.1 & 8.7 & 11.2 & & & & & 8.0 & 9.9 & & \\
\hline $\mathrm{R}$ & $\mathrm{P} 4$ & 8.4 & 10.2 & & & 8.2 & 10.2 & 8.2 & 10.2 & & & & \\
\hline $\mathrm{L}$ & $\mathrm{P} 4$ & 8.4 & 10.0 & 9.2 & 11.4 & 7.7 & 10.2 & & & 7.6 & 9.4 & & \\
\hline $\mathrm{R}$ & M1 & 13.2 & 12.6 & & & 12.4 & 12.0 & 12.2 & 11.8 & & & & \\
\hline $\mathrm{L}$ & M1 & 12.9 & 12.3 & 14.0 & 13.0 & 12.4 & 12.2 & & & 10.5 & 11.0 & & \\
\hline $\mathrm{R}$ & M2 & 13.00 & 13.2 & & & 12.6 & 12.0 & 13.5 & 12.0 & & & & \\
\hline $\mathrm{L}$ & M2 & 13.2 & 13.2 & 14.0 & 13.6 & 12.6 & 12.2 & & & 12.3 & 11.0 & 13.1 & 11.4 \\
\hline $\mathrm{R}$ & M3 & 12.4 & 12.2 & & & 12.3 & 11.5 & & & & & & \\
\hline $\mathrm{L}$ & M3 & 12.4 & 12.2 & 13.2 & 12.7 & 12.0 & 11.0 & & & 9.2 & 8.8 & 12.5 & 10.6 \\
\hline
\end{tabular}

Isolated teeth from Tighennif

\begin{tabular}{llcc}
\hline \hline $\mathrm{R}$ & Lower I1 & - & 6.7 \\
$\mathrm{R}$ & Lower I2 & 7.1 & 7.0 \\
$\mathrm{~L}$ & Lower C & 9.0 & 10.0 \\
$\mathrm{~L}$ & Upper dm1 & 8.3 & 9.8 \\
$\mathrm{~L}$ & Upper dm2 & 10.3 & 11.7 \\
$\mathrm{R}$ & Upper M1-M2 & 12.0 & 14.5 \\
\hline \hline
\end{tabular}

Table I-Dental dimensions ( $\mathrm{mm}$ ) of the Tighennif and Gran Dolina-TD6 mandibles and isolated teeth. H: Hominids 1 (ATD6-5 mandible and isolated teeth), 7 (ATD6-96 mandible) and 10 (ATD6-113 mandible) from TD6. MD: mesiodistal; BL: buccolingual.

Tabl. I - Dimensions ( $\mathrm{mm}$ ) des dents isolées et des dents en place des mandibules de Tighennif et Gran Dolina-TD6. H: Hominidés 1 (mandibule ATD6-5 et dents isolées),

7 (mandibule ATD6-96), et 10 (mandibule ATD6-113) de la Gran Dolina-TD6. MD: mésio-distal ; BL : bucco-lingual. 


\begin{tabular}{|c|c|c|c|c|c|c|c|c|c|c|c|c|}
\hline & \multicolumn{2}{|c|}{ Tighennif 1} & \multicolumn{2}{|c|}{ Tighennif 2} & \multicolumn{2}{|c|}{ Tighennif 3} & \multicolumn{2}{|c|}{ ATD6-5 } & \multicolumn{2}{|c|}{ ATD6-96 } & \multicolumn{2}{|c|}{ ATD6-113 } \\
\hline & $\mathrm{T}$ & $\mathrm{H}$ & $\mathrm{T}$ & $\mathrm{H}$ & $\mathrm{T}$ & $\mathrm{H}$ & $\mathrm{T}$ & $\mathrm{H}$ & $\mathrm{T}$ & $\mathrm{H}$ & $\mathrm{T}$ & $\mathrm{H}$ \\
\hline Corpus at M1 & 19.8 & 36.2 & 16.6 & 33.4 & 19.5 & 37.0 & 16.3 & 26.7 & 16.6 & 28.5 & $19.0^{*}$ & $31.0^{*}$ \\
\hline Corpus at LP & 23.2 & 37.5 & 22.2 & 31.2 & 23.7 & 36.0 & - & - & 18.6 & 27.5 & 20.0 & 32.0 \\
\hline Ramus breadth & \multicolumn{2}{|c|}{-} & \multicolumn{2}{|c|}{45.8} & \multicolumn{2}{|c|}{47.3} & \multicolumn{2}{|c|}{-} & \multicolumn{2}{|c|}{40.6} & \multicolumn{2}{|c|}{-} \\
\hline Ramus height & \multicolumn{2}{|c|}{-} & \multicolumn{2}{|c|}{78.5} & \multicolumn{2}{|c|}{85.6} & \multicolumn{2}{|c|}{-} & \multicolumn{2}{|c|}{60.0} & \multicolumn{2}{|c|}{-} \\
\hline Symphysis height & \multicolumn{2}{|c|}{36.0} & \multicolumn{2}{|c|}{33.3} & \multicolumn{2}{|c|}{37.5} & \multicolumn{2}{|c|}{-} & \multicolumn{2}{|c|}{-} & \multicolumn{2}{|c|}{-} \\
\hline
\end{tabular}

Table II-Measurements (mm) of the Tighennif and Gran Dolina-TD6 mandibles. T: thickness; H: height. Tabl. II - Mesures (mm) des mandibules de Tighennif et de la Gran Dolina-TD6. T : épaisseur ; H : hauteur.

\begin{tabular}{|c|c|c|c|}
\hline Species & Thickness, mm (n) & Height, mm (n) & Robustness (n) \\
\hline Homo habilis & $19.7 \pm 2.3(5)$ & $29.3 \pm 2.2(4)$ & $64.5 \pm 5.3(4)$ \\
\hline H. ergaster & $19.8 \pm 1.4(8)$ & $31.2 \pm 2.8(8)$ & $63.8 \pm 5.0(8)$ \\
\hline H. erectus (Java)* & $21.3 \pm 3.9(5)$ & $38.8 \pm 5.3(5)$ & $54.9 \pm 5.8(5)$ \\
\hline H. erectus (China)** & $16.5 \pm 1.8(7)$ & $28.6 \pm 3.3(7)$ & $58.0 \pm 5.6(7)$ \\
\hline Tighennif & $18.6(3)$ & $35.5(3)$ & $52.4(3)$ \\
\hline Sidi Abderraman & 17.0 & 35.8 & 47.5 \\
\hline H. antecessor & $17.3(3)$ & $28.7(3)$ & $60.2(3)$ \\
\hline H. heidelbergensis + & $16.4 \pm 1.7(16)$ & $30.8 \pm 3.4(16)$ & $53.4 \pm 5.1(16)$ \\
\hline H. neanderthalensis ++ & $15.3 \pm 1.7(21)$ & $32.1 \pm 3.3(21)$ & $47.9 \pm 5.1(21)$ \\
\hline
\end{tabular}

Data are given as means $\pm \mathrm{SD}$

\# This sample includes East African Early and Middle Pleistocene adult specimens KNM-ER 730, KNM-ER 731, KNM-ER 992, KNM-BK 67, KNM-BK 8518, OH 22, $\mathrm{OH} 23$, and $\mathrm{OH} 51$.

* This sample includes the Sangiran mandibles 1B, 5, 8, and 9 .

** This sample includes the mandibles from Zhoukoudian, Lantian, Hexian, and PA86.

${ }^{+}$This sample includes the Arago, Atapuerca-Sima de los Huesos, Mauer and Montmaurin specimens (see Rosas, Bermúdez de Castro 1999).

++ See Rosas and Bermúdez de Castro (1999) for the composition of this sample.

Table III-Measurements of the mandibular body at the level of M1 in some Homo species and specimens. Tabl. III - Mesures du corps mandibulaire (épaisseur, hauteur et robustesse) au niveau de la première molaire (M1) chez quelques espèces et spécimens du genre Homo. 


\begin{tabular}{|c|c|c|c|}
\hline Mandibular features & State A & State B & State C \\
\hline 1 - Position of mental foramen & P3-P4 & P4-M1 & M1 \\
\hline 2 - Position of the anterior marginal tubercle & $\mathrm{P} 3-\mathrm{P} 4$ & P4-M1 & M1 \\
\hline 3 - Position of the lateral prominence & M2 & M2-M3 & M3 \\
\hline 4 - M3 in relation to ramus (retromolar space) & Coverted & Partially coverted & Uncovered \\
\hline 5 - Inclination of the retromolar area & Vertical & Oblique & Horizontal \\
\hline $\begin{array}{l}6 \text { - Position of mylohyoid line in relation to alveolar margin at } \\
\text { M3 level }\end{array}$ & Low & Medium & High \\
\hline 7 - Trajectory of mylohyoid line in relation to alveolar margin & Parallel & Intermediate & Diagonal \\
\hline 8 - Relief of masseteric fossa & Deep & Shallow & Flat \\
\hline 9 - Relief of pterigoyd fossa & Shallow & Flat & - \\
\hline 10 - Gonion profile & Expanded & Regular & Truncated \\
\hline 11 - Position of condyle in relation to mandibular notch & Lateral & Medial & - \\
\hline 12 - Posterior subalveolar fossa & Shallow & Moderately hollowed & Deep \\
\hline 13 - Alveolar prominence & Present & Absent & - \\
\hline
\end{tabular}

Table IV-State of the mandibular features analyzed in table V [partially modified (features and scores) from Rosas (2001)].

Tabl. IV - État des caractéristiques mandibulaires analysées dans le tableau V [modifié partiellement (caractéristiques et état) d'après Rosas (2001)].

Figure 4 shows a clear relationship between increasing robusticity and decreasing corpus height in Pleistocene hominin mandibles. The plot shows two pairs of regression lines clearly differentiated. The lowest two lines correspond to $H$.neanderthalensis and H.heidelbergensis, although they do not show especially high correlation coefficients $(0.264$ and 0.318 , respectively). These lines are almost superimposed, with a slope of $-0.744(p$-value $=0.020)$ and a constant of 71.87 for $H$.neanderthalensis and a slope of -0.835 (p-value $=0.023$ ) and a constant of 79.15 for H.heidelbergensis. The upper lines correspond to $H$. erectus and $H$.ergaster but, although they are superimposed, the line corresponding to H.erectus is not significant $(\mathrm{p}$-value $=0.301)$ due to the presence of outliers such as Sangiran 6. However, H. ergaster line presents a significant regression model $(\mathrm{p}$-value $=0.003)$, with a correlation coefficient of 0.735 .

The slopes of the regression lines are almost the same for all the groups analyzed, but the lines corresponding to the more primitive groups are above the ones corresponding to later species, such as $H$. heidelbergensis and $H$. neanderthalensis. This could imply that in more recent groups, a given corpus width tends to be related to a lower corpus height, whereas the same corpus width would correspond to a higher height in more primitive groups.

Regarding to the species analyzed in this study, we can observe that Tighennif and Sidi Abderraman specimens are located nearby the H. ergaster regression line (they 

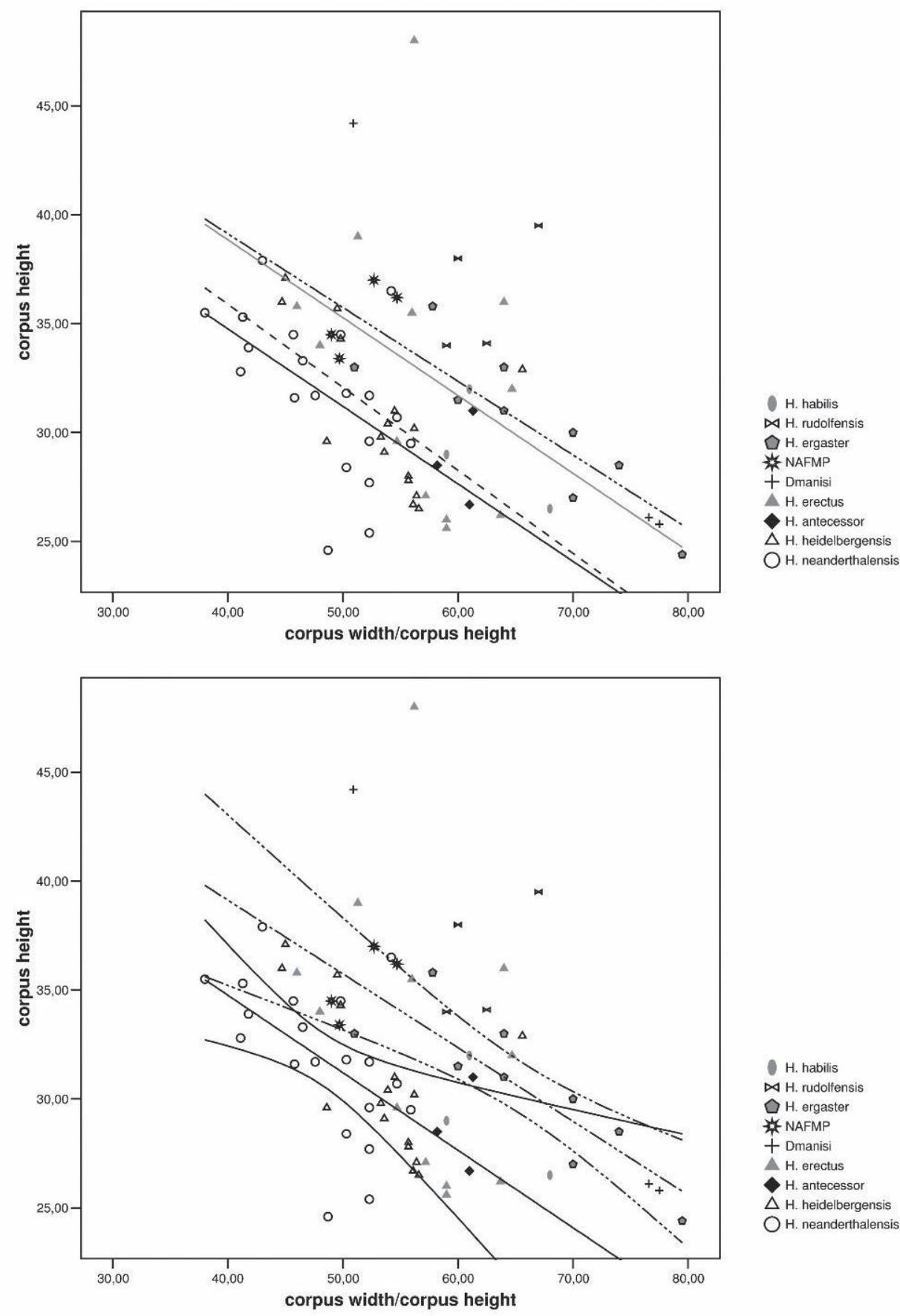

Fig. 4-Robusticity index versus mandibular height. A. Regression line for H. ergaster, H. erectus, H. heidelbergensis and $\mathrm{H}$. neanderthalensis. B. Confidence intervals at $95 \%$ for $\mathrm{H}$. ergaster and $\mathrm{H}$. neanderthalensis. It is important to note the position of Tighennif and Gran Dolina-TD6 in the plot (see text for explanation), as well as the big difference in the corpus index/corpus height ratio between D 2600 and both D 211 and D 2735 Dmanisi mandibles, as it was previously noticed (Skinner et al. 2006;

Bermúdez de Castro et al. submitted). D 2735 is located over $\mathrm{H}$. ergaster line, whereas D 211 is located on the $\mathrm{H}$. neanderthalensis line. Both individuals, however, display low corpus height compared with their corpus width, whereas D 2600 is out of the main point cloud due to its elevated corpus height. NAFMP: North Africa Middle Pleistocene fossils (Tighennif and Thomas Quarry).

Fig. 4 - Graphique qui met en rapport l'indice de robustesse et la hauteur du corps mandibulaire. A. Ligne de régression pour H. ergaster, H. erectus, $\mathrm{H}$. heidelbergensis et $\mathrm{H}$. neanderthalensis. B. Intervalles de confiance à $95 \%$ pour $\mathrm{H}$. ergaster et $\mathrm{H}$. neanderthalensis. Notez la position des spécimens de Tighennif et de la Gran Dolina-TD6 dans le graphique (voir le texte pour une explication détaillée) ainsi que la grande différence entre D 2600, d'une part, et D 211 et D 2735 d'autre part, comme l'ont signalé d'autres auteurs (Skinner et al. 2006 ; Bermúdez de Castro et al. soumis). D 2735 est placé au-dessus de la ligne de H. ergaster, tandis que D 211 est placé sur la ligne de H. neanderthalensis. Ces deux spécimens de Dmanisi présentent cependant une grande épaisseur du corps mandibulaire par rapport à la hauteur, tandis que D 2600 se situe à l'écart, du fait de la

grande hauteur de son corps mandibulaire. NAFMP : fossiles du Pléistocène moyen du Nord de l'Afrique (Tighennif et Thomas Quarry). 
all are included in the mean confidence interval at the 95\% for this regression model, as it is showed in fig. 4). Nevertheless, Gran Dolina individuals are mainly located close to the $H$. neanderthalensis line with the exception of the ATD6-78 specimen that lies closer to the H. ergaster line but still close to the limit of the $H$. neanderthalensis interval of confidence (fig. 4).

Concerning morphological features, the main mental foramen is placed at the P3-P4 level in the three Tighennif specimens, a primitive feature shared with H.habilis, $H$. ergaster, H. erectus, H. antecessor, and the Dmanisi mandibles (D 211, D 2735, and D 2600) (table V). In Tighennif 3 the right side exhibits two additional foramina at the P4-M1 level, whereas in the left side three secondary foramina at the P4 and P4-M1 level are also present. Multiple foramina are common in early specimens like Mauer, ATD6-96 or in the totality of the Zhoukoudian sample (Tobias 1991). The anterior marginal tubercle is well marked (especially in the right side) and placed at the P3-P4 level in Tighennif 1. It is also marked in Tighennif 2 and placed at the P4 level, just behind the main foramen. In Tighennif 3, this tubercle is not well differentiated from the prominent marginal torus, which starts at the P3 level and ends up at the lateral prominence level. The Tighennif specimens are also plesiomorphic for this feature, if we consider that the first appearance of this trait (anterior marginal tubercle at the C-P3 level) occurs in some early Homo specimens, such as $\mathrm{OH} 37$, KNM-ER 1802, or D 211 (Rosas, Bermúdez de Castro 1998). A minor difference between these specimens and the Tighennif mandibles is that the anterior marginal tubercle is placed in a slightly backward position in the North Africa specimens. Interestingly, the specimen ATD6-96 from Gran Dolina lacks anterior marginal tubercle and thus, it differs from the Tighennif mandibles. The lateral prominence is marked in Tighennif 1 and 2, and rather less

\begin{tabular}{|c|c|c|c|c|c|c|c|c|}
\hline & & & & Homo & & & & \\
\hline $\begin{array}{l}\text { Mandibular } \\
\text { features }\end{array}$ & habilis & ergaster & $\begin{array}{c}\text { erectus } \\
\text { (Java) }\end{array}$ & $\begin{array}{l}\text { erectus } \\
\text { (China) }\end{array}$ & Tighennif & antecessor & $\begin{array}{c}\text { heidel- } \\
\text { bergensis }\end{array}$ & $\begin{array}{l}\text { neander- } \\
\text { thalensis }\end{array}$ \\
\hline 1 & A & A, B & A & $\mathrm{A}, \mathrm{B}$ & A & $\mathrm{A}$ & $\mathrm{B}, \mathrm{C}$ & $\mathrm{C}$ \\
\hline 2 & $\mathrm{~A}, \mathrm{O}$ & $\mathrm{A}, \mathrm{O}$ & A & $\mathrm{A}, \mathrm{O}$ & A & $\mathrm{O}$ & $\mathrm{A}, \mathrm{B}, \mathrm{C}$ & $\mathrm{A}, \mathrm{B}, \mathrm{C}$ \\
\hline 3 & A & $\mathrm{C}$ & A & B & A, B & A & $\mathrm{C}$ & $\mathrm{C}$ \\
\hline 4 & A & A, B & A, B & $\mathrm{B}, \mathrm{C}$ & B & B & $\mathrm{B}, \mathrm{C}$ & $\mathrm{C}$ \\
\hline 5 & A & A, B & A, B & A, B & B & $\mathrm{B}$ & $\mathrm{B}, \mathrm{C}$ & $\mathrm{C}$ \\
\hline 6 & A, B & A, B & A, B & A & A & A & A & $\mathrm{A}, \mathrm{B}, \mathrm{C}$ \\
\hline 7 & A & A, B & A & A & A, B & A & $\mathrm{A}, \mathrm{B}, \mathrm{C}$ & $\mathrm{B}, \mathrm{C}$ \\
\hline 8 & A & $\mathrm{A}, \mathrm{B}, \mathrm{C}$ & A & $\mathrm{A}$ & A, B & B & $\mathrm{A}, \mathrm{B}, \mathrm{C}$ & $\mathrm{B}, \mathrm{C}$ \\
\hline 9 & - & A & A & A & A & A & A, B & B \\
\hline 10 & - & $\mathrm{A}, \mathrm{B}$ & - & A, B & A, B & $\mathrm{B}$ & $\mathrm{B}, \mathrm{C}$ & $\mathrm{B}, \mathrm{C}$ \\
\hline 11 & - & A & - & $\mathrm{A}$ & A & A & A, B & B \\
\hline 12 & A & A & A & $\mathrm{C}$ & $\mathrm{B}$ & $\mathrm{B}$ & $\mathrm{B}, \mathrm{C}$ & $\mathrm{C}$ \\
\hline 13 & A & $\mathrm{A}$ & A & $\mathrm{A}, \mathrm{B}$ & $\mathrm{A}$ & B & A, B & B \\
\hline
\end{tabular}

Table $V$-State of the mandibular features listed in table IV in different Homo species and groups.

Tabl. V-État des caractéristiques mandibulaires numérotées dans le tableau IV chez différentes espèces et groupes du genre Homo. 
pronounced in Tighennif 3. In Tighennif 1 it is advanced and located at the M2 level, like in the TD6 specimens. In Tighennif 2 and Tighennif 3 the lateral prominence is placed at the M2 and M2-M3 level, respectively. Again, this feature is primitive in this mandibular sample and shared with the Early Pleistocene European and African Homo species as well as with Asian H. erectus (table V). In the Dmanisi specimens, D 211 and D 2735, the lateral prominence is advanced and placed at the M1-M2 level, whereas in D 2600 it is located at the M2-M3 level.

As it is seen in norma lateralis, the M3 is partially covered by the ramus in Tighennif 1 , Tighennif 2 , and the left side of Tighennif 3. In the last specimen, the M3 is almost visible in norma lateralis. The primitive status in Homo for this feature is a M3 totally covered by the ascending ramus, as it happens in KNM-ER 1501, OH 13, OH 37, OH 7, KNM-WT 15000, KNM-BK 8518, or in D 2735. Thus, the Tighennif mandibles exhibit a first derived state that also appears in H.ergaster and the Eurasian Early and Middle Pleistocene specimens, including the TD6 specimens (table V), although in these cases no retromolar space is present. The trigonum postmolare is oblique in the three Tighennif mandibles, although in Tighennif 1 this area tends to be more horizontal. However, we cannot affirm that this specimen shares this trait with the Neanderthals and Atapuerca-Sima de los Huesos mandibular sample, where a broad and horizontal retromolar space is well developed as a true apomorphic feature. The length of the trigonum postmolare is about $7.0 \mathrm{~mm}$ in Tighennif 1 , less than $5.0 \mathrm{~mm}$ in Tighennif 2 and between 8.0 and $9.0 \mathrm{~mm}$ in Tighennif 3. In ATD6-96 the trigonum postmolare measures $7.0 \mathrm{~mm}$, whereas in ATD6-113 the value is 7.2. According to Rosas (2001) this would be the primitive condition observed in Homo.

The medial aspect of the Tighennif mandibles approaches that of H. ergaster (KNM-ER 992, KNMWT 15000, KNM-ER 730), and H. erectus from Java. At the M3 level, the mylohyoid line is 14.4, 11.4, and $16.0 \mathrm{~mm}$ below the alveolar margin in Tighennif 1,2 , and 3, respectively. Furthermore, the mylohyoid line is subparallel (Tighennif 1 and 2) and almost parallel to the alveolar border in Tighennif 3. In both the mylohyoid orientation and position, the Tighennif specimens preserve the primitive status, shared with most Homo species, except $H$. neanderthalensis, the Atapuerca-Sima de los Huesos hominins (table $V$ ) and surprisingly, the D 2600 mandible from Dmanisi. The subalveolar fossa in both the Tighennif and TD6 mandibles is moderately hollowed, thus deviating from the primitive condition (shallow or practically absent subalveolar fossa) observed in H.habilis, H.ergaster, and H.erectus from Java (table V). The alveolar prominence is well developed in the Tighennif mandibles as in other African Early and Middle Pleistocene specimens and thus, it diverges from the derived condition (no sign of alveolar prominence) observed for instance in $H$. antecessor and the Eurasian Pleistocene specimens. In the TD6 mandibles, the mylohyoid groove forms a small angle with the alveolar margin: $35^{\circ}$ in ATD6-5, $42^{\circ}$ in ATD6-96 and $37^{\circ}$ in ATD6-113. The mylohyoid groove is more vertical and the angle substantially higher in the Tighennif specimens: $67^{\circ}$ in Tighennif 2 , and $60^{\circ}$ in Tighennif 3 . It is noteworthy to mention that in this trait, TD6 fossils show the lowest values recorded for the genus Homo (Rosas, Bermúdez de Castro 1999), with the exception of KNM-ER 820 and KNM-WT 15000 that, however, are juveniles. Thus, with regard to this feature, the Gran Dolina specimens are clearly dissimilar to the African Middle Pleistocene mandibles.

In early Homo specimens, the posterior symphyseal surface is characterized by a strong superior transverse torus and an extremely inclined alveolar planum. This is the case for H. habilis (OH 13, OH 37), and KNM-ER 1805 , or the Dmanisi specimens, but also for some H. ergaster mandibles (KNM-BK 8518, and $\mathrm{OH} 22$ ). This shelf-like structure is less pronounced in African and Asian Middle Pleistocene hominins, as well as in Javanese H. erectus (Sangiran 1, 5, 8, and 22: Kaifu et al. 2005). Tobias (1991: p. 329) estimated the angle between the alveolar planum and the dental alveolar plane to quantify this feature. According to Tobias estimations, the value of this angle is $22^{\circ}$ in $\mathrm{OH} 13,25^{\circ}$ in $\mathrm{OH} 37$, whereas in Tighennif 1 , 2 , and 3 the values are $43^{\circ}, 36^{\circ}$, and $48^{\circ}$, respectively. In ATD6-96, the only TD6 specimen in which it is possible to measure this angle, the value is $60^{\circ}$ and thus, in this trait, the Gran Dolina-TD6 specimens would be more derived than those from Tighennif.

In the Tighennif mandibles the relief of the masseteric fossa is relatively excavated as in most Pleistocene hominins, whereas the relief of the pterigoyd fossa is shallow. In both features, the Tighennif specimens do not deviate from the primitive condition observed in the genus Homo. Likewise, the Tighennif specimens retain the primitive condition for the position of the condyle in relation to mandibular notch. In fact, the crest defining the mandibular notch meets the condyloid process in the lateral part of the articular surface instead in the medial part, which is the derived condition observed in 
Neanderthals. The gonion profile is expanded or regular in the Tighennif mandibles and regular in ATD6-96.

The shape of the alveolar arcade of the Tighennif 1 and 3 tends to be parabolic, whereas the Plio-Pleistocene East African specimens (e.g. OH 13, OH 37, or KNMER 1802), as well as the Dmanisi mandibles show a more narrow U-shaped arcade, with the canines located at the corners (Rosas, Bermúdez de Castro 1998; Kaifu et al. 2005). The length/width index of the alveolar arcade (infradental ID-M3 distance/bi-molar M3-M3 distance), which gives an objective measure of this shape, is lower than 100 in the Tighennif specimens and greater than 100 in OH 13, KNM-ER 1805, KNM-ER 992, KNM-BK 8518 , and in the three Dmanisi mandibles. According to Kaifu et al. (2005), the KNM-BK 67 is considerably distorted and the alveolar arcade of this specimen may be wider than we have previously estimated (Rosas, Bermúdez de Castro 1998). In the Javanese H. erectus Kaifu et al. (2005) obtain an index of 110 for Sangiran 9, and 108 for Sangiran 22, whereas in Chinese H. erectus, the values are lower: 92-83 in Lantian, and 88 in Zhoukoudian H1. A photographic restoration of the ATD6-96 mandible (see Carbonell et al. 2005) provides an index value of the alveolar arcade of about 100. Despite it is an estimation, it is clear that shape of the alveolar arcade in the Gran Dolina specimen is gently pointed, and the P3 is not aligned with the anterior dentition, as it is characteristic of Neanderthals.

The shape of the ramus in Tighennif 2 resembles that of ATD6-96. However, Tighennif 3 shows a particular ramus shape, with an extremely pronounced height, a prominent and massive coronoid process that exceeds the condyle in height, and with the deepest point of the notch being close to the condylar process. In ATD6-96 the coronoid process and condyle show a symmetrical appearance, and the deepest point of the mandibular notch is approximately equidistant to both processes.

\section{Teeth}

In a previous paper (Bermúdez de Castro et al. 1999) we observed some similarities between the teeth of the Hominid 1 from TD6 and the teeth of the Tighennif 3 specimen. With an enlarged sample, we can now see that the teeth of the TD6 Hominids 1 and 10 are large and comparable in size to those of Tighennif 1 and 3, although somewhat smaller than that of Tighennif 2 (table I). However, and taking into account that the sexual dimorphism factor can be reasonably discounted for size differences between samples, we see that the teeth of Hominid 7 are small and out of the variability of the Tighennif sample.

In addition, in a multivariate study of the dental measurements of I2-M2 using a shape distance and a principal component analysis of some Homo specimens, we observed certain proximity between the TD6 Hominid 1 and Tighennif 3 (Bermúdez de Castro et al. 1999). In general, dental proportions of these specimens are comparable (table I) and these observations have been precisely used by some authors to conclude that the two hominin samples may belong to a same species (Hublin 2001; Stringer 2003).

Recent and detailed dental studies have shed light to this matter concluding that the similarities between TD6 and Tighennif hominins are primitive for the genus Homo and that the fossils from Gran Dolina are more derived in some traits than the fossils from North African Middle Pleistocene (Martinón-Torres 2006; Martinón-Torres et al. 2006). In particular, North African Middle Pleistocene hominins show the same dental plesiomorphies and apomorphies as H. ergaster species (Martinón-Torres et al. 2007). Table VI summarizes some of the dental morphological traits that are relevant for comparison. Tighennif and Gran Dolina-TD6 fossils share some primitive dental traits like the expression of a buccal cingulum in lower canines and premolars and the shape of their lower P3s. In these groups, lower P3s are strongly assymetrical with an oblique maximum buccolingual diameter with regard to the mesio-distal diameter. These specimens display a wide talonid that comprises a distolingual and a distobuccal component. Preliminary geometric morphometric exploration of lower P3s shape (Martinón-Torres 2006) reveals that Tighennif and TD6 P3s share the same morphospace than the African Pliocene hominins. However, this conformation would be primitive for the genus Homo and, therefore, of restricted utility for taxonomical and phylogenetic assessment. In contrast, TD6 lower P4s show a transformation with respect to earlier hominins like H.habilis, H. ergaster, $H$. erectus, and the Dmanisi and Thigennif specimens. In contrast to a large and expanded occlusal polygon typical of primitive specimens, the occlusal polygon of TD6-Gran Dolina lower P4s undergoes a reduction and occupies a peripheral position with regard to the external outline (Martinón-Torres et al. 2006). Although this tooth class keeps some primitive traits such as the assymetrical contour and the development of accessory lingual cusps, 


\begin{tabular}{|c|c|c|}
\hline Feature & NAFMP & TD6 \\
\hline $\begin{array}{l}\text { Shovel shape } \mathbf{I} \mathbf{m} \mathbf{x} \\
\text { 0: classic shovel shape } \\
\text { 1: triangular shovel shape }\end{array}$ & 0 & 1 \\
\hline $\begin{array}{l}\text { Form of Cmx } \\
\text { 0: flared, "talonid"-like marginal } \\
\text { ridges, 1: incisor-like }\end{array}$ & 0 & 0 \\
\hline $\begin{array}{l}\text { Cingulum in } \mathbf{M x} \mathbf{C} \text { and } \mathbf{P m} \\
0 \text { : present 1: absent }\end{array}$ & 0 & 0 \\
\hline $\begin{array}{l}\text { Form of M1 mx } \\
0: \text { squared outline, distance between } \\
\text { lingual cusps }<\text { or }=\text { than between buccal cusps } \\
\text { 1: rhomboidal outline with protruding } \\
\text { hypocone and distance between lingual } \\
\text { cusps }>\text { than between buccal }\end{array}$ & 0 & 1 \\
\hline $\begin{array}{l}\text { M1 mxx/M2mx } \\
0: \mathrm{M} 1<\mathrm{M} 2,1: \mathrm{M} 1>\mathrm{M} 2\end{array}$ & 0 & 0 \\
\hline $\begin{array}{l}\text { Form of P3 } \mathbf{m d} \\
0 \text { : strongly assymetrical and } \\
\text { conspicuous talonid } \\
\text { 1: symmetrical or moderately symmetrical }\end{array}$ & 0 & 0 \\
\hline $\begin{array}{l}\text { Form of } \mathbf{P 4 m d} \\
0 \text { : assymetrical with expanded occlusal polygon } \\
\text { 1: assymetrical with reduced } \\
\text { occlusal polygon }\end{array}$ & 0 & 1 \\
\hline $\begin{array}{l}\text { Transverse crest in } \mathbf{P} \mathbf{4} \mathbf{m d} \\
0 \text { : commonly absent } \\
\text { 1: frequently present }\end{array}$ & 0 & 0 and 1 \\
\hline $\begin{array}{l}\text { Buccal talonid in P4md } \\
0 \text { : present, 1: absent }\end{array}$ & 0 & 1 \\
\hline $\begin{array}{l}\text { Mid-trigonid crest in M1 and/orM2 } \\
0: \text { frequently absent, } 1: \text { present }\end{array}$ & 0 & 1 \\
\hline $\begin{array}{l}\text { M1md/M2md sequence } \\
0: \mathrm{M} 1<\mathrm{M} 2,1: \mathrm{M} 1 \geq \mathrm{M} 2\end{array}$ & $0^{*}$ & 0 \\
\hline $\begin{array}{l}\text { M2md/M3md sequence } \\
0: \mathrm{M} 2<\mathrm{M} 3,1: \mathrm{M} 2 \geq \mathrm{M} 3\end{array}$ & 1 & 1 \\
\hline
\end{tabular}

NAFMP: North African Middle Pleistocene populations

For the size sequence of molar series we calculated crown computed area (CCA). We consider that $\mathrm{Xi}=\mathrm{Xj}$ if $\mathrm{CCA} \mathrm{Xi} / \mathrm{CCA} \mathrm{Xj}$ is $>0.96$ and $<1.04$.

* Rabat is M1 > M2

Table VI-Comparative summary of some dental morphological traits in North African Middle Pleistocene and Gran Dolina-TD6 hominins. 
TD6 hominins, Middle Pleistocene populations from Europe and H.neanderthalensis have lost the buccal component of the talonid that characterizes the hominin species from the Pliocene and the Early Pleistocene from Africa and Asia. This buccal component of the talonid is so conspicuous in Tighennif specimens that is delimitated in the occlusal contour of the teeth by a characteristic buccal indentation (fig. 5). This conformation suggests that, despite belonging to the early Middle Pleistocene, Tighennif fossils would have kept the primitive state whereas the Early Pleistocene TD6 fossils would have started a different evolutionary path.

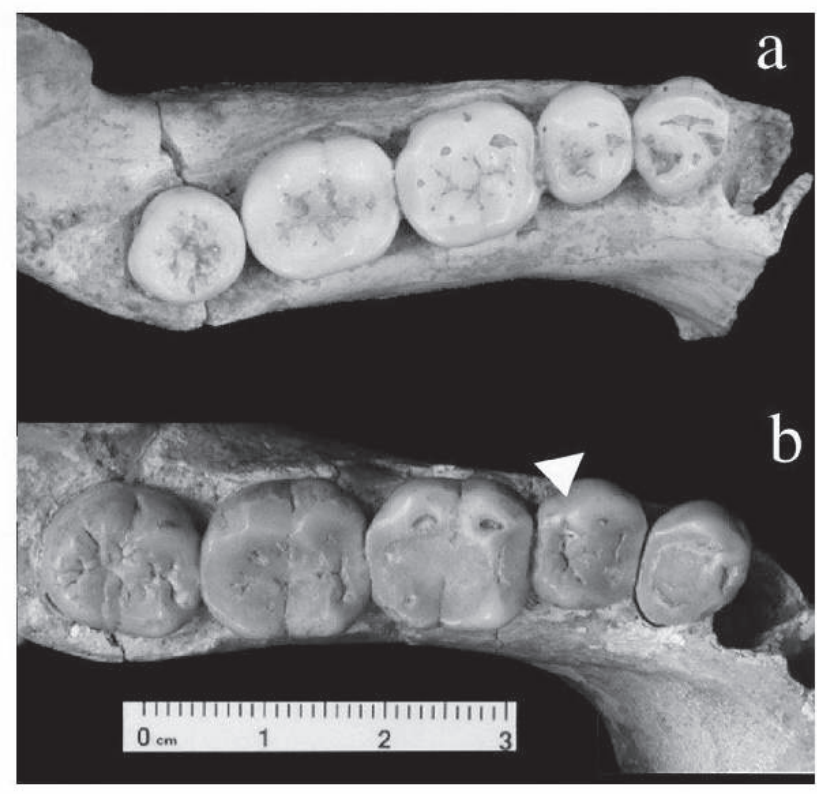

Fig. 5-P3 to M3 occlusal view of ATD6-96 (a) and Tighennif 2 (b). Note the primitive aspect of P3s in both specimens and the differences between P4s morphology. In Tighennif, the arrow head points the buccal delimitation of the buccal component of the talonid that TD6 fossils have lost (see text for explanation). Note also the size difference between the two mandibles.

Fig. 5 - Vue occlusale de ATD6-96 (P3-M3) (a) et Tighennif 3 (P3-M3) (b). Notez l'aspect primitif des $P 3$ chez les deux spécimens et la différence morphologique entre les P4. Chez Tighennif, la flèche montre la délimitation buccale du talonide, qui est absente sur les fossiles de la Gran Dolina-TD6. Notez aussi la différence de taille entre les deux mandibules.

Although no upper dental remains were recovered from the Tighennif site, we can make some inferences by comparing TD6 fossils with the Rabat specimen, since it has been also assigned to the same group as the Thigennif mandibles (Thomas, Vallois 1977). Rabat specimen shows a classic shovel shape that despite being pronounced does not display the incipient triangular shovel shape described in $H$. antecessor and H. erectus (Martinón-Torres 2006; Martinón-Torres et al. 2007). In these groups, the enlarged marginal ridges define a deep and narrow longitudinal lingual fossa that gives to the occlusal view a characteristic triangular shape (Martinón-Torres et al. in press). This conformation will be more pronounced in the European Middle Pleistocene populations and $H$.neanderthalensis, becoming the typical condition in these groups (Martinón-Torres 2006; Martinón-Torres et al. 2007). Similarly, Rabat upper first molars keeps the primitive shape for the genus Homo with a quadrangular outline and expanded occlusal polygon whereas TD6 fossils present a rhomboidal contour with relative distal displacement of the lingual cusps and the protrusion in the external outline of a bulging hypocone (Gómez-Robles et al. in press).

\section{DISCUSSION AND CONCLUDING REMARKS}

The earliest evidence of hominins in the Maghreb is the Ain Hanech site in Algeria, which could date back to the Olduvai subchron (1.770-1.950 kyrs), according to the faunal remains and the paleomagnetic data (Sahnouni 1998; Sahnouni, Heinzelin (de) 1998; Sahnouni et al. 2002; Sahnouni, Derradji in press; but see also Geraads et al. 2004). The Ain Hanech site has yielded a lithic assemblage of Oldowan technology similar to those recovered from Olduvai Bed I and Lower Bed II and Koobi Fora (Sahnouni et al. 2002). In Morocco, the oldest lithic assemblage comes from the late Early Pleistocene deposits of unit L of the Thomas Quarry 1 site, dated of circa 1.0 Ma (Raynal et al. 2001; Rhodes et al. 2006). The lithic assemblage consists of Acheulean artefacts made of quartzite and flint.

Although it may be possible to recognize some small differences between early and late populations (Sahnouni, Derradji in press), the North African human occupation may have been continuous during the entire Early and Middle Pleistocene. During the Middle Pleistocene, hominins who were able to manufacture the Acheulean technology occupied a relatively narrow fringe between the Mediterranean coast and the Sahara desert. The later would have operated as a geographic barrier during cold and arid events (Demenocal 1995) for the genetic contact between the Maghreb and the African tropical populations. These isolation periods may have produced 
local endemism and genetic drift, leading to the formation of particular paleodemes (in the sense of Howell 1999) or subspecies in this African region.

The possible genetic contact between these paleodemes and the southern European hominids across the Gibraltar Strait should not be discarded during warm and cold events, when the distance between Africa and Europe diminished to 6.5 km(Alimen 1975; Giles-Pacheco, Santiago Pérez 1987; Arribas, Palmqvist 2002; Finlayson 2002). These authors use either the archaeological or the paleontological evidence for their suggestions. However, direct paleoanthropological comparative data for the late Lower-early Middle Pleistocene was not available until now.

In the present study we have observed that the Tighennif and Gran Dolina-TD6 mandibles share some plesiomorphic traits for the genus Homo (features 1, 3, $6,7,9$, and 11 in table $I V$ ). From the cladistic point of view, these traits are not useful for taxonomical purposes. Furthermore, certain lengthening of the mandibular corpus produces in the Tighennif mandibles the appearance of a short and inclined retromolar area and that their reduced $\mathrm{M} 3 \mathrm{~s}$ are not totally hidden by the ramus, as seen in norma lateralis (traits 4 and 5 in table IV). The Tighennif mandibles share this derived structural pattern with H. erectus, H. ergaster, and H. antecessor. The absence of alveolar prominence (feature 13 in table $I V$ ) in the Gran Dolina specimens clearly separates this hominin sample from the northwest African group. Furthermore, ATD6-96 does not exhibit the strong backwards inclination of this surface and the markedly developed alveolar plane that is present in the Tighennif specimens. Likewise, the development of the superior transverse torus (Tighennif 3) is absent in ATD6-96. The shape of the ramus in Tighennif 3 is also completely different from that of ATD6-96, especially with regard to the incisura semilunaris profiles, which is almost symmetrical in ATD6-96, whereas in Tighennif 3 it exhibits an absolutely high coronoid process compared with the condylar height.

On the other hand, the Gran Dolina specimens are remarkably smaller than those of Tighennif, and lack the robustness which characterizes the African Pleistocene mandibles. The scatter biplot of the robustness index against the corpus height shows that primitive specimens tend to possess higher corpus for a given corpus width than later groups (fig. 4). In this graph it can be also observed that Tighennif specimens, as well as Sidi Abderraman one, display this trend of having very high corpus height in relation to their corpus width. Two out of the three $H$. antecessor studied specimens follow the trend of more recent groups by displaying low mandibles in relation to their width. Thus, the main difference between both groups in terms of mandibular dimensions can be related to the higher corpus height characteristic of Tighennif individuals.

The dental evidence reveals that North African Middle Pleistocene populations are morphologically closer to H. ergaster populations than to H. antecessor groups (Martinón-Torres 2006; Martinón-Torres et al. 2007). Although some similitude can be found between Tighennif and TD6 teeth, those features are plesiomorphic for the genus Homo and therefore, of limited discriminative power for taxonomical and phylogenetic purposes. However, despite their primitive morphology, $H$. antecessor teeth show some dental specializations more typical of the Pleistocene Eurasian populations that would be ratifying different evolutionary stories (Martinón-Torres et al. 2007). These features would be in accordance with a previous work that stated a possible Asian origin for the Gran Dolina TD6 populations (Carbonell et al. 2005). Compared to the African Pleistocene species from H.habilis to North African Middle Pleistocene populations, anterior dentitions of the hominin groups found in the Eurasian continent are generally characterized by higher frequencies of the most pronounced grades of mass additive traits (term by Irish 1988), such as shovel shape, cingular derivates, mesial canine ridge and strong labial convexity (Martinón-Torres 2006; Martinón-Torres et al. 2007). This pattern could be the morphological translation of the tendency to the relative expansion of the anterior dentition ascertained in the Middle Pleistocene populations (Wolpoff 1971). This trend will reach its maximum expression with European Middle Pleistocene and $H$. neanderthalensis populations although its expression as well as incipient degrees of triangular shovel shape or the particular conformation of their upper first molars can be traced back in H. erectus (for the triangular shovel shape) and H.antecessor populations (for both traits) (Martinón-Torres et al. in press). Interestingly, Tighennif populations, despite belonging to the Middle Pleistocene, are out of this trend. Furthermore, posterior dentitions in the fossil populations of the Eurasian Pleistocene (H.erectus, H. antecessor, $H$. heidelbergensis and $H$. neanderthalensis) show some qualitative traits derived from dentognathic reduction processes particularly pronounced in later Homo populations (Kaifu et al. 2005; Martinón-Torres 2006; 
Martinón-Torres et al. 2007). Among those traits we can find the lower P4s morphology which highlights different evolutionary trends between Tighennif and TD6 populations.

In this report, it has been described a mandibular and dental "gigantism" in North African Pleistocene populations with dimensions that overpass contemporaneous populations from the European Middle Pleistocene (Bermúdez de Castro et al. 1997; Bermúdez de Castro, Rosas 1998) and even H. erectus (see Kaifu et al. 2005). It has been also stated that Middle Pleistocene fossils from North Africa may represent a morphological divergence of this part of the continent (Hublin 1989). The persistence of a marked macrodontism in the North African series could be the result of a regional evolutionary continuity or the adaptation of some local conditions (Hublin 1989). In our opinion, this particular combination of primitive traits with a relative "gigantism" with respect to other contemporaneous populations suggest that the North African group could be the result of an evolution in isolation of an $H$. ergaster subpopulation.

From all these evidences we consider that the Tighennif hominins, together with other contemporaneous (Thomas Quarry and Oulad Hamida 1), and perhaps later North African specimens (Sidi Abderrahaman, Salé, and Rabat [Kebitat]) belong to a hominin lineage, independent from the European lineage which include the Gran DolinaTD6 hominins. For those who are prepared to accept that the African Early Pleistocene hominins (H.ergaster) and the Asian Early Pleistocene hominins (H. erectus) should be included in different species, and considering authoritative opinions of some workers (e.g. Wood 1992; Klein 1999; Schwartz, Tattersall 1999; Tattersall 2000) as well as our evolutionary study of the dental hominin evidence (Martinón-Torres 2006; Martinón-Torres et al. 2007), we suggest that H. ergaster mauritanicus is a reasonably taxonomical option for this Maghrebian group.

Finally, since the Italian Ceprano calvaria belongs to the same chronological age range than the TD6 hominins (see Manzi 2004), it would be also interesting to make a comparative study between this specimen and the cranial remains from Tighennif.

\section{Acknowledgements}

We give many thanks to Prof. Pascal Tassy, Prof. Dominique Grimaud-Hervé and Dr. Amélie Vialet, from the Muséum national d'histoire naturelle de Paris, for permission to accede the Tighennif hominins and for their help and facilities during the study of the fossils. We are also grateful to Prof. Emiliano Aguirre for allowing the use of the beautiful original pictures of the Tighennif specimens. We thank Jean Triquet for his help in the French translation, and two anonymous referees for helping us to improve the manuscript with their useful comments. Authors also acknowledge to the Gran Dolina field team, and in particular to Eudald Carbonell, their dedication and effort made during the excavation of the TD6 level. This research was supported by funding from the Dirección General de Investigación of the Spanish Ministerio de Educación y Ciencia (MEC), Project N ${ }^{\circ}$ CGL2006-13532C03/BTE, and the Cátedra Atapuerca from the Fundación Atapuerca and Fundación Duques de Soria. Fieldwork at Atapuerca is supported by the Consejería de Cultura y Turismo of the Junta de Castilla y León. Aida Gómez has the benefit of a predoctoral FPU grant of the Spanish MEC. 


\section{BIBLIOGRAPHY}

Alimen (H.) 1975, Les «isthmes » hispano-marocain et siculo-tunisien aux temps acheuléens, L'Anthropologie $79: 399-436$

ANTÓN (S.C.) 2002, Evolutionary significance of cranial variation in Asian Homo erectus, American Journal of Physical Anthropology 118: 301-323.

Arambourg (C.) 1954a, L'Atlanthropus de Ternifine, Lybica 2: 425-439.

Arambourg (C.) 1954b, L'hominien fossile de Ternifine (Algérie), Comptes Rendus des Séances de l'Académie des Sciences, Paris, 239 : 893-895.

Arambourg (C.), Hoffstetter (R.) 1963, Le gisement de Ternifine I, Archives de l'Institut de Paléontologie Humaine, Mémoire 2 : 1-190.

Arribas (A.), PalmQvist (P.) 1999, On the ecological connection between sabre-tooths and hominids: faunal dispersal events in the Lower Pleistocene and a review of the evidence for the first human arrival in Europe, Journal of Archaeological Science 26: 571-585.

Arsuaga (J.L.), Martinez (I.), Gracia (A.), Lorenzo (C.) 1999, The Sima de los Huesos crania (Sierra de Atapuerca, Spain), A comparative study, Journal of Human Evolution 33: 219-281.

BabÁ (H.), Aziz (F), Kaifu (Y.), Suwa (G.), Kono (R.T.), JACOB (T.) 2003, New Homo erectus calvarium from the Pleistocene of Java, Science 299: 1384-1388.

Bermúdez de CASTRo (J.M.) 1993, Dental remains from Atapuerca (Spain) I. Metrics, Journal of Human Evolution 15: 265-287.

Bermúdez de Castro (J.M.), Arsuaga (J.L.), CARbonell (E.), Rosas (A.), Martínez (I.), Mosquera (M.) 1997, A hominid from the Lower Pleistocene of Atapuerca, Spain: possible ancestor to Neandertals and modern humans, Science 276: 1392-1395.

Bermúdez de Castro (J.M.), Rosas (A.), Nicolás (M.E.) 1999, Dental remains from Atapuerca-TD6 (Gran Dolina site, Burgos, Spain), Journal of Human Evolution 37: 523-566.
Carbonell (E.), Bermúdez DE CAstro (J.M.), Arsuaga (J.L.), Díez (J.C.), Rosas (A.), CuencaBescós (G.), Sala (R.), Mosquera (M.), RodríGuez (X.P.) 1995, Lower Pleistocene hominids and artifacts from Atapuerca-TD6 (Spain), Science 269: 826-830.

Carbonell (E.), Bermúdez de Castro (J.M.), Arsuaga (J.L.), Allué (E.), Bastir (M.), Benito (A.), Cáceres (I.), CANals (T.), Díez (J.C.), VAN DER Made (J.), Mosquera (M.), Ollé (A.), PérezGonZÁlez (A.), RodríGueZ (J.) and (X.P.), Rosas (A.), Rosell (J.), SAla (J.), Vallverdú (J.), Vergés (J.M.) 2005, An Early Pleistocene hominin mandible from Atapuerca-TD6, Spain, Proceedings of the National Academy of Sciences, USA, 102: 5674-5678.

Demenocal (P.B.) 1995, Plio-Pleistocene African climate, Science 270: 53-59.

FALguères (C.), Bahain (J.-J.), Yokoyama (Y.), Arsuaga (J.L.), Bermúdez de Castro (J.M.), Carbonell (E.), Bischoff (J.L.), Dolo (J.-M.) 1999, Earliest humans in Europe: the age of TD6 Gran Dolina, Atapuerca, Spain, Journal of Human Evolution 37: 343-352.

FinLAYSON (C.) 2002, The role of climate in the spatiotemporal pattern of human colonization and extinction in the Pleistocene with specific reference to the Mediterranean Region, in B. Ruiz-Zapata et al. (éds), Quaternary Climatic Changes and Environmental Crises in the Mediterranean Region, Universidad de Alcala de Henares, Madrid, p 1-8.

Gabounia (L.), Lumley de (M.-A.), Vekua (A.), LoRdKipAnidZe (D.), Lumley de (H.) 2002, Découverte d'un nouvel hominidé à Dmanissi (Transcaucasie, Géorgie), Comptes Rendus Palevol 1 : 243-253.

Gabunia (L.), Vekua (A.) 1995, A Plio-Pleistocene hominid from Dmanisi, East Georgia, Caucasus, Nature 373: 509-512.

GeraAds (D.), Hublin (J.-J.), Jaeger (J.-J.), Tong (H.), Sen (S.), Toubeau (P.) 1986, The Pleistocene hominid site of Ternifine, Algeria: new results on the environment, age, and human industries, Quaternary Research 25: 380-386.

GeraAds (D.), Raynal (J.-P.), Eisenmann (V.) 2004, The earliest human occupation of North Africa: a reply to 
Sahnouni etal. 2002, Journal of Human Evolution 46: 751-761.

Giles-Pacheco (F.), SAntiago Pérez (A.) 1987, El poblamiento del sur de la Península Ibérica en el Pleistoceno Inferior a través de Gibraltar, in E. Ripoll Perelló (ed.), Actas del Congreso Internacional "El Estrecho de Gibraltar" 1, UNED, Ceuta, p 97-109.

Gómez-Robles (A.), Martinón-Torres (M.), BermúdeZ de Castro (J.M.), Margvelashvili (A.), Bastir (M.), Arsuaga (J.L.), Pérez-Pérez (A.), Estebaranz (F.), MARTíneZ (L.M.) in press, A geometric morphometric analysis of hominin upper first molar shape, Journal of Human Evolution, doi:10.1016/j.jhevol.2007.02.002

Grimaud-Hervé (D.), Widianto (H.), JACOB (T.) 2000, Two new human fossils discovered in Sangiran (Central Java, Indonesia), Acta Anthropological Sinica (suppl.) 19: 41-45.

Howell (F.C.) 1960, European and Northwest African Middle Pleistocene hominids, Current Anthropology 1: 195-232.

Howell (F.C.) 1999, Paleo-demes, species clades, and extinctions in the Pleistocene hominin record, Journal of Anthropology Research 55: 191-243.

Hublin (J.-J.) 1989, Les origines de l'homme moderne: Europe occidentale et Afrique du Nord, in G. Giacobini (ed.), Hominidae, Proccedings of the 2nd International Congress of Human Paleontology (Turin), Jaca Book, Milan, p. 423-430.

Hublin (J.-J.) 2001, Northwestern African Middle Pleistocene hominids and their bearing on the emergence of Homo sapiens, in L. Barham, K. Robson-Brown (eds), Human Roots: Africa and Asia in the Middle Pleistocene, Western Academic and Specialist Press, Bristol, p. 99-121.

IRISH (J.D.) 1988, Diachronic and synchronic dental trait affinities of Late and Post-Pleistocene peoples from North Africa, Homo 49: 138-155.

KAIFU (Y.), BABA (H.), AZIZ (F.), Indriati (E.), SCHERENK (F.), JACOB (T.) 2005, Taxonomic affinities and evolutionary history of the Early Pleistocene hominids of Java: Dentognathic evidence, American Journal of Physical Anthropology 128: 709-726.

Klein (R.) 1999, The Human Career, Human Biological and Cultural Origins, The University of Chicago Press, Chicago.
Le gros Clark (W.E.) 1964, The Fossil Evidence for Human Evolution, 2nd ed., University of Chicago Press, Chicago.

MANZI (G.) 2004, Human evolution at the Matuyama-Brunhes boundary, Evolutionary Anthropology 13: 11-24.

MARTINÓn-TorRes (M.) 2006, Estudio de los dientes humanos del Pleistoceno de Sierra de Atapuerca (Burgos), PhD dissertation. Santiago de Compostela University, Spain.

MARTINÓN-TorRes (M.), BASTIR (M.), BERMÚdez de CASTRO (J.M.), Gómez (A.), Sarmiento (S.), Muela (A.) 2006, Hominin lower second premolars morphology: evolutionary inferences through geometric morphometric analysis, Journal of Human Evolution 50: 523-533.

MartinÓn-Torres (M.), Bermúdez de CASTRo (J.M.), Gómez-Robles (A.), Arsuaga (J.L.), CARbonell (E.), LordKipanidZe (D.), MANZi (G.), MargVelashyili (A.) 2007, Dental evidence on the hominin dispersals during the Pleistocene, Proceedings of the National Academy of Sciences, USA, 104: 13 279-13 282.

Martinón-Torres (M.), Bermúdez de CASTRo (J.M.), Bastir (M.), Gómez (A.), Sarmiento (S.), Muela (A.), Lozano (M.), Arsuaga (J.L.) in press, Gran DolinaTD6 and Sima de los Huesos dental samples: preliminary approach to some dental traits of interest for phylogenetic studies, in S. Bailey, J.-J. Hublin (eds), Dental Perspectives on Human Evolution, Springer-Verlag, Berlin.

PArés (J.M.), PÉReZ-GonZÁlez (A.) 1995, Paleomagnetic age for Hominid fossils at Atapuerca site, Spain, Science 269: 830-832.

PARÉs (J.M.), PÉREZ-GonZÁlez(A.) 1999, Magnetochronology and stratigraphy at Gran Dolina section, Atapuerca (Burgos, Spain), Journal of Human Evolution 37: 325-342.

Raynal (J.-P.), Sbihi-Alaoui (F.Z.), Geraads (D.), Magoga (L.), MohiB (A.) 2001, The earliest occupation of North Africa: the Moroccan perspective, Quaternary International 75: 65-75.

Rhodes (E.J.), Singarayer (J.S.), RAynal (J.-P.), Westaway (K.E.), SBihi-Alaoul (F.Z.) 2006, New age estimates for the Paleolithic assemblages and Pleistocene succession of Casablance, Morocco, Quaternary Science Review 25: 2569-2585. 
RIGHTMIRE (G.P.) 1990, The evolution of Homo erectus, comparative anatomical studies of an extinct human species. Cambridge University Press, New York.

RightMiRE (G.P.) 1996, The human cranium from Bodo, Ethiopia: evidence for speciation in the Middle Pleistocene? Journal of Human Evolution 31: 21-39.

Rightmire (G.P.), LORdKIPANIDZE (D.), VeKuA (A.) 2005, Anatomical descriptions, comparative studies and evolutionary significance of the hominin skulls from Dmanisi, Republic of Georgia, Journal of Human Evolution 50: 115-141.

RosAS (A.) 2001, Occurrence of Neanderthal features in mandibles from the Atapuerca-SH site, American Journal of Physical Anthropology 114: 74-91.

Rosas (A.), Bermúdez de CASTRO (J.M.) 1998, On the taxonomic affinities of the Dmanisi mandible (Georgia), American Journal of Physical Anthropology 107: 145-162.

Rosas (A.), Bermúdez de CASTRo (J.M.) 1999, The ATD6-5 mandibular specimen from Gran Dolina (Atapuerca, Spain), Morphological study and phylogenetic implications, Journal of Human Evolution 37: 567-590.

SAhnouni (M.) 1998, The Lower Paleolithic of the Maghreb: Excavations and analysis at Ain Hanech, Algeria, Cambridge Monographs in African Archaeology 42, BAR International Series 689, Archaeopress, Oxford.

SAHnouni (M.), DerRAdJi (A.) in press, The Lower Palaeolithic of the Maghreb: Current state of knowledge, Adumatu Journal.

SAhnouni (M.), Heinzelin de (J.) 1998, The site of Ain Hanech revisited: new investigations at this Lower Pleistocene site in Northern Algeria, Journal of Archaeological Science 25: 1083-1101.
Sahnouni (M.), Hadjouis (D.), Made VAN Der (J.), DerRadjI (A.), CANALS (A.), MEdiG (M.), Belahrech (H.), Harichane (Z.), Rabhi (M.) 2002, Further research at the Oldowan site of Ain Hanech, Northeastern Algeria, Journal of Human Evolution 43: 925-937.

SchwartZ (J.), TatTersall (I.) 1999, Morphology and diversity in fossil hominids: accepting Homo erectus and Homo ergaster as separate taxa is just the beginning, American Journal of Physical Anthropology 28, suppl. 246.

SKinNer (M.M.), GoRdon (A.D.), COLlaRd (N.J.) 2006, Mandibular size and shape variation in the hominins at Dmanisi, Republic of Georgia, Journal of Human Evolution 51: 36-49

STRINGER (C.B.) 2003, Out of Ethiopia, Nature 423: 692-694.

Tattersall (I.) 2000, Paleoanthropology: The last halfcentury, Evolutionary Anthropology 4: 2-16.

Thomas (A.), Vallois (H.V.) 1977, Les dents de l'Homme de Rabat, Bulletins et Mémoires de la Société d'Anthropologie de Paris 4 : 31-58.

TOBIAS (P.V.) 1991, Olduvai Gorge. 4: the skulls, endocasts and teeth of Homo habilis, Cambridge University Press, Cambridge, $921 \mathrm{p}$.

Wolpoff (M.H.) 1971, Metric trends in hominid dental evolution, Case Western Reserve University, Studies in Anthropology 2: 1-244.

Wood (B.) 1992, Origin and evolution of the genus Homo, Nature 355: 783-790. 